\title{
Disputas, compartilhamentos e exclusões rituais num cemitério público brasileiro
}

\author{
Andreia Vicente da Silva*
}

\section{Resumo}

A literatura a respeito da presença do religioso no espaço público brasileiro tem afirmado mais contemporaneamente que os encontros entre as alternativas religiosas se marcam principalmente por compartilhamentos. Contudo, persiste a ideia de que os evangélicos se posicionam nessa arena a partir da perspectiva da oposição, o que também tem sido interpretado como um possível direcionamento ao fundamentalismo. Neste artigo, analiso o caso da revitalização do cemitério público de Praia de Mauá, Magé, que é uma pequena cidade histórica na Baixada Fluminense no Rio de Janeiro. A partir das ações do administrador evangélico do cemitério, procuro pontuar como a predominância simbólica do catolicismo dialoga com o novo modelo de gestão secular e de que forma a junção desses elementos produz exclusões dos rituais distintos da matriz cristã.

Palavras-chave: Espaço público. Cemitério. Secularidade. Compartilhamento religioso. Evangélicos.

\section{Disputes, sharings and ritual exclusions in a brazilian public cemetery}

\section{Abstract}

The literature concerning religious presence in Brazilian public space has assured more contemporaneously that the links among the religious alternatives have occurred mainly by shares. However, the idea persists that evangelicals, in this area, are against this perspective, which has also been understood as a possible direction to fundamentalism. Thus, this paper aims at analyzing the revitalization case of a public cemetery in Praia Mauá, Magé, which is a small historical town in Baixada Fluminense in Rio de Janeiro, Brazil. According to the evangelical cemetery manager's decision-making, it was pointed

\footnotetext{
* Mestre em Antropologia (UFF) e Doutora em Ciências Sociais (UERJ). Professora Adjunta do Programa de Pós-graduação em Ciências Sociais (UNIOESTE). E-mail: deiavicente@ gmail.com Currículo Lattes: http://buscatextual.cnpq.br/buscatextual/visualizacv. do?id=K4770456 T0
} 
out how the symbolic predominance of Catholicism dialogues with the new model of a secular management and how the association of these elements produces exclusions of rituals that are different from the Christian matrix.

Key-words: Public zone. Cemetery. Secularity. Religious sharing. Evangelicals.

\section{Disputas, sobreposiciones y exclusiones rituales en un cementerio público brasileño}

\section{Resumen}

La literatura sobre la presencia religiosa en el espacio público brasileño ha asegurado de forma más contemporánea que los vínculos entre las alternativas religiosas se han producido principalmente por acciones. Sin embargo, persiste la idea de que los evangélicos, en esta área, están en contra de esta perspectiva, que también se ha entendido como una posible dirección hacia el fundamentalismo. Por lo tanto, este trabajo tiene como objetivo analizar el caso de revitalización de un cementerio público en Praia Mauá, Magé, que es una pequeña ciudad histórica en Baixada Fluminense en Río de Janeiro, Brasil. De acuerdo con la toma de decisiones del administrador del cementerio evangélico, se señaló cómo el predominio simbólico del catolicismo dialoga con el nuevo modelo de gestión secular y cómo la asociación de estos elementos produce exclusiones de rituales que son diferentes de la matriz cristiana.

Palabras clave: Zona pública. Cementerio. Secularidad. Compartir religioso. Evangélicos.

\section{Introdução}

Não é pequena a lista de estudos a respeito das influências do catolicismo na formação do espaço público brasileiro. Afinal, como já foi insistentemente argumentado, essa predominância iniciou-se no período colonial, quando seus representantes desembarcaram nestas terras com os primeiros colonizadores. Autores renomados das ciências humanas e sociais já defenderam que o pioneirismo católico permaneceu, embora remodelado, mesmo após a laicização do Estado com o advento da República (GIUMBELLI, 2008; MONTERO, 2006).

No que diz respeito às representações e as práticas associadas à morte e aos mortos, a predominância do catolicismo é evidente em diversos contextos: cemitérios ao lado de igrejas católicas, terços e rezas, Dia dos Mortos, aparições de almas. Esses e muitos outros signos e símbolos povoam o nosso imaginário quando pensamos os contextos relacionados a finitude (REIS, 1991; MARTINS, 1983; RODRIGUES, 2005). O fato é que o rito católico constitui um marco por meio do qual os comportamentos associados à morte e aos mortos foram se desenvolvendo no Brasil, seja por aproximação, oposição ou complementaridade. 
Analisando a literatura a respeito do trânsito religioso, percebemos uma aposta no modelo da convivência e do compartilhamento entre as diferentes religiosidades como uma das características da realidade brasileira desde os tempos coloniais. Em grande parte dos estudos de religião, embora o catolicismo colonial tenha sido monopolizador e tenha marcado a paisagem e os hábitos religiosos, existiam outras religiosidades convivendo com as práticas e representações católicas. O candomblé e a umbanda, por exemplo, apareceram em nossa produção como parte da religiosidade brasileira e, ao mesmo tempo, como exemplos de uma rica contribuição ritual. A originalidade da nossa cultura sempre foi explicada a partir do hibridismo, das soluções ímpares e originais que aqui aconteceram, permitindo o cruzamento de legados distintos (BASTIDE, 2001).

Todavia, a partir da perda do monopólio católico de organização do espaço público, o argumento da laicização do Estado ganhou força, embora o religioso com suas diferentes "presenças" continuasse atuando em diferentes frentes políticas, econômicas e sociais (GIUMBELLI, 2008: 80). Naquele novo momento de secularização dos cemitérios, o impulso (re)ordenador dava conta de que as intervenções sobre o lugar dos mortos operassem a partir de tentativas de alocar os ritos religiosos na esfera civil ${ }^{1}$ (MONTERO, 2006). Ou seja, nos novos cemitérios seculares todos os cidadãos poderiam ser enterrados. Contudo, como espaço público, as necrópoles secularizadas passariam a ser utilizadas a partir de diferentes lógicas, entre elas a religiosa. Por isso mesmo, pode-se afirmar que foi preciso encontrar certos ordenadores espaço-rituais a fim de que a realização de rituais religiosos específicos pudesse ocorrer sem ferir o compartilhamento civil. Na prática, contudo, o que se percebe é que esses ordenadores seguem sendo majoritariamente cristãos.

De toda forma, sob o ponto de vista daquela tradição anterior de riqueza ritual e sincretismo, o novo momento de secularização do Estado Brasil, que

O paradigma da secularização (WEBER, 2004) envolveria um movimento histórico fruto da modernidade e estimulado pelo ascetismo protestante. Para Montero (2006: 48 e 54), há duas consequências principais da desmistificação da experiência religiosa: por um lado a força secularizadora da ética protestante que teria subjetivado a experiência religiosa e, por outro, a conjugação entre a reforma protestante e a emergência dos Estados modernos e da ciência que teria aprofundado o processo de diferenciação das esferas retirando a religião do espaço público. No Brasil, apontou a autora, uma das consequências desse movimento foi a alocação da religião na sociedade civil em que, ao longo do tempo, foram desenvolvidos parâmetros regulatórios da forma e da intensidade possíveis para as suas manifestações no ambiente público. 
culminou com o surgimento do protestantismo, deu lugar a um campo de disputas religiosas. ${ }^{2}$ Tanto a última constatação é verdadeira que o crescimento do movimento evangélico durante algum tempo representou uma enorme provocação aos pesquisadores brasileiros dos anos 1960 e 1970, que o pensavam como desafiador das características de porosidade expressivas da religiosidade em nosso país (TEIXEIRA e MENEZES, 2006). Contudo, com o tempo, os estudiosos perceberam que essa separação não foi tão absoluta e que na verdade existiam trocas entre o universo evangélico e as opções religiosas que estavam presentes no centro do seu sistema ritual (MAFRA e ALMEIDA, 2009).

Eu mesma, em meus estudos a respeito dos rituais de morte dos evangélicos da Assembleia de Deus (AUTORA, 2011), percebi na forma como ritualizam a morte evidências de estratégias distintas em relação aos conteúdos rituais de outras religiosidades. Cito alguns exemplos. Durante o enterro evangélico há uma evitação da permanência no interior do cemitério. A passagem pela necrópole é muito rápida, restringindo-se ao cortejo que visa depositar o caixão na sepultura. De acordo com meus informantes, eles não retornam ao cemitério para visitar os túmulos por não acreditarem na possibilidade de intercessão pelos mortos. Por sua vez, alguns evangélicos me contaram que sonham com seus mortos durante o luto, acionando lógicas de aproximação com os mortos que não estão previstas no sistema de representações. Outro exemplo é o uso de objetos dos mortos pelos enlutados pentecostais. Os objetos-pessoas demonstram uma tendência à convivência com o morto que é negada no plano do rito de enterro. Ou seja, eu percebi, nos seus comportamentos no cemitério e na forma como ritualizam a morte, múltiplas possibilidades de interação entre vivos e mortos e com conteúdos rituais de outras religiosidades.

Estudos recentes têm dado conta de uma realidade de embates entre alternativas religiosas - que atingem principalmente as expressividades afrobrasileiras -, assim como forte influência da religião na política. Nessa arena, a pecha de fundamentalistas ${ }^{3}$ recai majoritariamente sobre os evangélicos

$2 \mathrm{Na}$ multiplicidade anterior, as expressões religiosas conviviam e os cientistas sociais utilizavam termos como sincretismo e hibridismo para expressar essas trocas. Nessa nova multiplicidade, o conceito de "alternativas religiosas" surge como expressão de um universo religioso concorrencial (MONTERO, 2006: 63).

3 Aqui é importante esclarecer que o termo fundamentalista é utilizado por lideranças dos movimentos sociais contra os evangélicos como categoria de acusação nos debates políticos. Por sua vez, historicamente está associada a uma postura de literalismo bíblico, embora também possa ser aplicado a outros campos como forma de marcar posição, inclusive na economia (ALVES, 2010: 24). 
(ALMEIDA, 2017), embora se possa afirmar com segurança que a Igreja Católica manteve seu lugar de privilégio diante do Estado, mesmo depois da segunda metade do século XX (ORO, 2011), influenciando as pautas políticas ao longo de toda a história da nação (MACHADO, 2012). De fato, o que se percebe é que a união de cristãos (evangélicos e católicos) em torno de pautas conjuntas tem produzido e ampliado embates, tanto no campo intrarreligioso quanto na arena dos direitos humanos. Vide, no último caso, a ação das Frentes parlamentares católica e evangélica na tentativa de "impor a todos os cidadãos a visão de um segmento religioso e moldar a ordem social a partir dela" (VITAL e LEITE LOPES, 2017: 115) ou os casos de intolerância narrados por adeptos das religiões africanas que denunciam agressões verbais, físicas e simbólicas (ROCHA, PUGGIAN e RODRIGUES, 2011).

Neste artigo, meu objetivo principal é entrar no debate a respeito das disputas entre alternativas religiosas no uso do espaço público. Para tanto, analiso o caso da revitalização do cemitério de Praia de Mauá, em Magé, que é uma pequena cidade histórica no interior do Estado do Rio de Janeiro. Por intermédio da apresentação das diretrizes para o ordenamento e para a higienização da necrópole impetrados pelo novo administrador do cemitério que é evangélico, minha intenção é compreender sentidos simbólicos compartilhados a respeito do espaço e dos rituais ali realizados. Ao mesmo tempo, problematizo continuidades e rupturas, pertencimentos e distinções, inclusões e exclusões em relação às religiosidades ali presentes.

O que pretendo comprovar é que o desenvolvimento de uma estrutura administrativa secular nos cemitérios incorporou traços pretéritos da ordenação espaço-ritual católica da morte. Ao analisar a ação do administrador evangélico, procuro evidenciar de que maneira o uso de elementos seculares e religiosos em conjunto conforma um modelo de gestão moderna cemiterial que acaba por operar a exclusão ritual das manifestações religiosas de luto distintas da matriz cristã. Nesse sentido, é possível propor certos questionamentos a respeito do fundamentalismo e mesmo do protagonismo evangélico nesse processo. Afinal, traços da perspectiva cristã operam em ação conjunta com o secular culminando numa gestão do espaço público que pode ser caracterizada como religiosamente excludente.

O trabalho de campo foi realizado no cemitério público de Praia de Mauá, entre os anos de 2008 e 2011. Praia de Mauá é o quinto distrito da 
cidade de Magé, ${ }^{4}$ no Estado do Rio de Janeiro, que é uma das mais antigas do Brasil fundada pelos portugueses em 1565. Logo nos primeiros anos de fundação foram erguidas diversas igrejas na localidade. Uma delas é a Igreja de Nossa Senhora da Guia ${ }^{5}$ que, no período colonial, como era comum, tinha a função de cemitério. Posteriormente, com a separação entre igreja e cemitério, um muro foi erguido entre as construções fazendo surgir o cemitério atual. No ano de 2010, devido à superlotação, um terreno foi adquirido na parte de trás do antigo cemitério e um novo muro foi erguido - o que deu origem à parte mais nova desse estabelecimento. A relação entre a matriz católica e o primeiro e o segundo segmentos da necrópole será essencial no meu argumento.

Durante a pesquisa, realizei diversas entrevistas e observações, tanto em dias comuns quanto nos feriados de finados. Meu principal objetivo naqueles anos era compreender a forma como os evangélicos da Igreja Assembleia de Deus lidavam com a morte e com os ritos de morte (AUTORA, 2011). Todavia, logo percebi que, como todo "território plural" (HAESBAERT, 2004), a morada dos mortos é reconhecida, significada e experimentada pelos diferentes atores sociais a partir da diversidade de seu entendimento do mundo. Essas diferenças implicam uma enorme riqueza que pode e deve ser problematizada pelos cientistas sociais. Andar pelo cemitério e questionar os seus sentidos e usos pode auxiliar nas propositivas a respeito da

4 De acordo com o IBGE cidades, em 2016, Magé possuía uma população de 227.322 pessoas. O salário médio mensal dos trabalhadores era de 1.8 salários mínimos e havia $12 \%$ de pessoas ocupadas. No que diz respeito à religião, 90.325 pessoas se declararam católicas, 78.411 evangélicas e 5.079 espíritas. Disponível em: https://cidades.ibge.gov.br/ $\mathrm{v} 4 /$ brasil/rj/mage/panorama

5 A "Igreja da Guia" é a matriz da Paróquia de Mauá. Essa primeira edificação foi fundamental na organização espacial já que o núcleo urbano se desenvolveu em torno da fazenda homônima. Atualmente, no seu entorno fica o cemitério de Mauá, a Praça Nossa Senhora da Guia, além da comunidade de pescadores da "Praia do Limão". Dessa praia, saem muitos barcos de turistas que vêm até Mauá para pescar nas águas mais profundas da Baía de Guanabara. Em Mauá existem outras duas igrejas católicas tombadas pelo IPHAN, são elas: Capela de Nossa Senhora dos Remédios (1740) e Capela de São Francisco do Croará (1745).

6 Haesbaert (2004) debate de forma longa os conceitos de território, territorialidade e multiterritorialidade. O conteúdo do território plural está em constante tensão, produzindo formas particulares de identidade. Nesse sentido, é possível pensar um mesmo território no qual os significados, a organização no espaço e a sua utilização sejam distintos, ou seja, territorialidades distintas. Contudo, o autor salienta que é possível que as múltiplas territorialidades sejam desigualmente acumuladas ao longo do tempo, como pretendo demonstrar no caso do cemitério em questão. 
diversidade, da tolerância e da convivência em tempos de fundamentalismos e conservadorismos tão arraigados. Por isso mesmo, esta reflexão procura evidenciar os limites dessas convivências a partir dos compartilhamentos e dos conflitos presenciados.

O fato é que quando iniciei meu trabalho de campo, no ano de 2008, deparei-me com um contexto de mudanças substanciais na dinâmica daquele cemitério. Conforme descreveram os meus entrevistados, era notável a transformação promovida pela nova gerência. Embora a necrópole já fosse administrada pelo município de Magé há muitos anos, somente mais recentemente passou a ser cuidada sistematicamente. Antigamente, o lugar estava abandonado aos "vândalos e aos ratos" durante praticamente o ano inteiro. Situação que só era suavizada na semana do dia de Finados.

Lembrando o passado de abandono, os informantes me contaram que era uma tristeza para qualquer parente ter que enterrar seu morto num ambiente degradado. Ao mesmo tempo, relataram orgulhosos as transformações a respeito da organização e da limpeza do cemitério. Com a nova administração e com o estabelecimento de regras mais rígidas de uso, aumentou o número de enterros. ${ }^{7}$ Contudo, surpreendentemente, na mesma velocidade, surgiram novos e graves conflitos.

Durante o tempo em que estive ali, ouvi muitos debates. Além do orgulho de alguns, percebi constrangimentos e reprovações por parte de outros. O fato é que as recentes tentativas de revitalização e organização do espaço cemiterial deram vazão a sentimentos contraditórios. Será justamente a partir desses elementos que procurarei compreender como a lógica secular e o pluralismo religioso convivem de maneira a consolidar ou excluir certos ordenamentos espaciais e práticas rituais. Contudo, há que se chamar atenção que as estratégias são múltiplas e se realizam num jogo de sentidos que envolve tanto "pertencimento" quanto "distinção".

Desde que chegou ao cemitério em 2006, quando foi designado para um cargo comissionado pela Prefeitura Municipal de Magé, o administrador iniciou uma série de mudanças no local principalmente no que diz respeito à conformação espacial e ao cotidiano ritual.

Sabe, quando eu cheguei aqui era tudo uma imundície. Tinha galinha, despacho pra todo lado. Os túmulos estavam quebrados. Os donos não

7 Todos os distritos da cidade de Magé possuem cemitérios. A maior parte deles segue o modelo de extensão das matrizes católicas históricas. 
cuidavam das suas sepulturas. O cemitério tava abandonado. Agora não, tá tudo arrumado e limpo. Tem que ter ordem. Não pode ficar sujando tudo não (ADMINISTRADOR, 27/07/2009).

Na ocasião da primeira entrevista, feita em 2008, o administrador se identificou como membro da Igreja Batista Central de Mauá, uma das igrejas evangélicas mais antigas da comunidade, com quarenta anos de fundação. $\mathrm{Na}$ tentativa de organizar o cemitério, ele realizou um censo de sepulturas perpétuas e estabeleceu uma série de proibições rituais. Juntando-se as medidas tomadas pelo administrador, buscando implementar uma gestão secular, a predominância histórica do catolicismo no cemitério e a visão evangélica daquele local, será possível compreender esses caminhos de ação. Primeiramente, me deterei no parâmetro espacial.

\section{O cemitério secular, lógica espacial católica}

O primeiro passo para o ordenamento espacial do cemitério foi realizar um censo de sepulturas. O objetivo de tal ação foi avaliar se os túmulos eram privados e se os mesmos eram cuidados pelos familiares. Hoje, somente são considerados inamovíveis os túmulos perpétuos, construídos e cuidados. Essa ação do administrador está em consonância com a legislação estadual, que prevê que a administração dos cemitérios pode queimar ou doar os restos mortais das sepulturas temporárias. ${ }^{8}$

Após terem realizado o censo, os trabalhadores do cemitério começaram a ordenar o local. O primeiro passo estabelecido foi que, para os novos enterramentos, eles privilegiaram a parte frontal e mais antiga do cemitério. A parte mais nova, de trás, em grande parte ainda desocupada, ficou reservada apenas para sepulturas perpétuas ou para os sepultamentos que ocorrem em ocasiões em que não há vagas disponíveis na parte mais antiga.

Como pretendo argumentar a partir de agora, a decisão de gerir o espaço por meio de uma distinção de padrões de ocupação para cada uma das duas partes do cemitério acionou sentidos e processos organizativos que apontam para uma complementaridade entre o modelo religioso fundador e a gestão

8 De acordo com o DE 3.707/1970, a administração do cemitério pode incinerar ou doar os restos mortais de sepulturas temporárias para instituições e estabelecimentos científicos de ensino ou pesquisa, mediante convênios previamente aprovados pela Diretoria de Controle Funerário da Prefeitura (art. 125, parágrafo $2^{\circ}$.). Os corpos que estão em sepulturas perpétuas podem ser exumados e recolocados na mesma sepultura que geralmente têm espaço para dois caixões e dez caixas de ossos (art. 121). 
moderna e laica. Há elementos presentes nas ações e nas falas dos interlocutores que permitem compreender o papel de cada um desses modelos.

Quando decidiu preservar a parte mais recente para os sepultamentos perpétuos, o administrador dialogava com certa lógica moderna e laica de ordenamento espacial que ambicionava construir e consolidar um novo modelo cemiterial no qual as quadras e ruas fossem retilíneas, proporcionais e seriadas. Ao explicar os motivos pelos quais adotava tal modelo, o administrador insistiu em apresentar o padrão antigo como uma "bagunça", especificando que não havia ruas para passagem nem ordenação dos túmulos. De forma distinta, a parte mais antiga e (hiper)ocupada da necrópole teve seu processo de ocupação organizado a partir dos ciclos de vida e morte da comunidade e seguiu padrões de desenvolvimento associados à matriz e à cosmologia católica. Aposto na ideia de que a relação entre esses sentidos e lógicas, embora distintas, constrói uma gramática complementar. Vejamos.

Quando entrevistei os enlutados, foi recorrente ouvi-los explicar a predileção pelo enterramento na parte frontal do cemitério, referindo-se a ela como "bonita, antiga e tradicional". Cada uma dessas palavras teve seus significados expostos num diálogo estreito com o modelo proposto pela nova administração. Ou seja, as intervenções propostas e executadas pela equipe cemiterial foram sendo gestadas e possibilitadas também pela lógica da comunidade. Nesse diálogo, as possibilidades e as impossibilidades de modernização do cemitério foram sendo construídas. Um quinhão de história ajuda a pensar.

O cemitério de Praia de Mauá surgiu ainda no período colonial como parte da Igreja de Nossa Senhora da Guia, que foi construída inicialmente no ano de 1647 de frente para a Baía de Guanabara e no alto de uma elevação. Como era de costume durante o período colonial, os enterramentos eram realizados na nave da igreja ou mesmo no terreno do seu entorno (REIS, 1991). Somente nos anos anteriores ou mesmo já no período do Império é que o cemitério foi separado da igreja e transferido para a parte debaixo do morro. Tal constatação pode ser comprovada pelo fato de que o túmulo

\footnotetext{
A história dessa igreja se confunde com a própria história do distrito, já que o início do processo de povoamento local se deu em 1597, quando Bastião Rodrigues começou as atividades em sua fazenda que tinha o mesmo nome da igreja. Aproximadamente cinquenta anos após receber suas terras, ele ordenou que fosse erguida a primeira capela da localidade em homenagem a Santa Margarida. Era o ano de 1647. Muito tempo depois, essa capela foi abandonada e ficou em ruínas. Ao ser reconstruída em 1683, recebeu um novo nome: "Igreja de Nossa Senhora da Guia".
} 
mais antigo que está no cemitério onde é hoje é o de João Locatelli, que foi enterrado em 1913, e o enterramento mais antigo na nave da catedral ser do ano de 1861.

Fazendo uma análise dos elementos que compõem o cemitério e ouvindo os relatos dos seus frequentadores, é possível comprovar a antiguidade da relação matriz católica e necrópole e os sentidos atribuídos a essa relação. O cemitério tem dois portões de entrada e saída, como é possível observar nas fotografias a seguir. O primeiro fica localizado no alto do morro ao lado da porta principal da igreja. O segundo foi construído posteriormente e está localizado ao lado do portão de saída da Igreja Matriz. A posição dos portões relembra o passado colonial, quando os mortos estavam aos cuidados da Igreja Católica e o cemitério e a matriz eram uma só construção. Com a separação entre igreja e cemitério, ${ }^{10}$ um segundo portão foi construído para permitir o trânsito dos corpos sem precisar acessar o templo católico. Porém, tanto a posição do próprio cemitério que ladeia a igreja quanto a do portão de entrada que se localiza muito próximo ao acesso à matriz indicam uma aproximação efetiva entre as duas construções.

Comparando o modelo anterior e as ações da administração atual na gestão do espaço cemiterial, podemos aprofundar a compreensão da gramática que dita a beleza e a tradicionalidade tal qual elencadas como preferenciais pela população.

Antigamente, a escolha do lugar para os sepultamentos era feita usando apenas como parâmetro principal a proximidade da matriz católica e a sequência natural das mortes. Vê-se que, na parte frontal do cemitério, não há ordenação dos sepultamentos por meio de uma rigidez cronológica nem ruas específicas para passagem. Caminhando com dificuldade entre os túmulos que ocupam toda área em declive do terreno encontrei, por exemplo, um túmulo de 1955 ao lado de outro de 1913.

Outro dado essencial é compreender que na parte frontal do cemitério o visual tradicionalmente católico é mais marcado, principalmente se levarmos em consideração o posicionamento lateral da Igreja Matriz. As sepulturas têm estilo e conformação própria dos tempos mais antigos. O método a

10 A separação entre o Estado e a religião aconteceu a partir do advento da República no Brasil (GIUMBELLI, 2008: 81) quando a Igreja Católica perdeu seu monopólio de intervenção no espaço público e a sociedade brasileira adquiriu características de um "estado secular", onde o religioso teria sido alocado na esfera civil (MONTERO, 2006). Contudo, embora a Igreja Católica tenha perdido seu poder de legítima organizadora do espaço público, ela conservou ainda influência como agente constituidor desse ambiente. 
partir do qual os túmulos estão dispostos é aquele dos sucessivos "ciclos de vida" da comunidade. Geração após geração, a cada morte, um novo elemento foi introduzido ali. O planejamento foi feito tomando-se como base os acontecimentos do momento e o espaço construído acaba por revelar e evidenciar essas diferentes etapas de sedimentação da história do lugar.

Ao longo do tempo, o chão do cemitério foi sendo sucessivamente reaproveitado sem que se pensasse em exumar os corpos já sepultados. Com a necessidade de novos túmulos, buscavam-se brechas no terreno e lá sepultavam. Quando não houve mais como cavar no chão, passou-se a construir gavetas verticais. Com o passar dos anos, o cemitério adquiriu uma formatação que é considerada pela administração atual como "desordenada", já que não há ordem cronológica nem delimitação fixa de espaços. São camadas sobrepostas, que revelam um entendimento do mundo e que marcam uma forma de construir a história.

Ao mesmo tempo, nessa primeira parte do cemitério estão os jazigos perpétuos das famílias mais antigas do lugar. ${ }^{11}$ Atualmente, conseguir construir um jazigo familiar imponente na primeira parte é quase impossível, justamente pela formatação que esse espaço adquiriu. Essa impossibilidade faz que os enlutados sintam que um sepultamento na parte frontal evidencie privilégio e "exclusividade".

De forma distinta, na parte posterior e mais nova há delimitação fixa de ruas, e cada uma delas é separada por duas carreiras de sepulturas que se organizam inversamente. O desenho dessa nova parte é bem diferente daquele visualizado no segmento mais antigo. Há sempre espaço reservado especificamente para passagem. Os túmulos estão dispostos seguindo retas e o espaço entre eles é proporcional.

Segundo o que o coveiro e o administrador me relataram, o objetivo das novas diretrizes ordenadoras é manter uma organização espacial da parte mais nova que se baseie em ruas e que privilegie as perpetuidades. Nas palavras do coveiro, se evitaria "a bagunça que acontece na outra parte (frontal)". Por isso é que eles procuram aproveitar o espaço já ocupado da frente para o maior número de sepultamentos, reservando o segmento posterior somente para sepultamentos perpétuos ou em momentos nos quais não há vagas para enterro na outra parte. Quando isso não acontece, no tempo propício o corpo é retirado e enterrado na vala comum onde ficam os esqueletos daqueles mortos que não são cuidados pelas famílias.

$\overline{11}$ Encontrei, por exemplo, um jazigo familiar datado do ano de 1938. 
Como ficou evidente no campo, de maneira geral as novas regras espaciais estabelecidas pela equipe do cemitério não geraram conflitos. Isso porque, em geral, há concordância entre o método escolhido pela administração e a preferência dos usuários. O administrador me explicou que ao escolher o local da sepultura procura, dentro das possibilidades, atender aos pedidos dos parentes do morto que na maior parte das vezes privilegiam a parte da frente. Nesse caso, a "desordem e o caos" (tal qual explicitados pelo administrador) não são questionados. Na verdade, a conformação mais antiga e desestruturada é vista com predileção. Para os familiares, a parte ocupada mais recentemente tem menor valor.

\section{Cemitério católico, gestão secular}

Sabe, quando eu cheguei aqui era tudo uma imundície. Tinha galinha, despacho pra todo lado. Os túmulos estavam quebrados. Os donos não cuidavam das suas sepulturas. O cemitério tava abandonado. Agora não, tá tudo arrumado e limpo. Tem que ter ordem. Não pode ficar sujando tudo não. (...)

Se um familiar quiser fazer suas orações e colocar suas velas não tem problema não. Cada um pode cuidar do seu túmulo como quiser. Prestar homenagens, colocar flores, pintar, lavar. Respeitamos o sentimento de todos (ADMINISTRADOR, 27/07/2009).

No que diz respeito às proibições rituais, as decisões do administrador apontam para uma tentativa de "higienização" seletiva do espaço. Como o trecho da entrevista citada exemplifica, ele vetou a utilização dos itens rituais que são especificamente usados pelos adeptos da umbanda e do candomblé, citando-os como poluidores: galinha, despachos, cachaça e pipoca. Todavia, alguns objetos rituais são permitidos. As velas, as flores, as fotos e os bilhetes podem ser utilizados e são reconhecidos como homenagens legítimas. Ao fazer uma retrospectiva de sua atuação com relação ao cotidiano ritual do cemitério, é possível perceber que o administrador aciona lógicas seculares e religiosas para a construção dos sentidos que legitimam sua ação. Como pretendo demonstrar, a fusão da gramática católica na administração que se pretende secular resultou na exclusão dos rituais afro-brasileiros.

A afirmação de que os cemitérios públicos brasileiros são laicos precisa e deve ser problematizada para avançarmos na argumentação. Em tese, não há controle religioso desses espaços que estão submetidos ao Estado. Este pode parecer um comentário simples, mas não é. Afinal, embora de fato os 
cemitérios públicos não sejam legalmente ordenados com base em princípios religiosos, a maioria deles está muito longe de ser subtraída da dominação de instituições e símbolos religiosos (BERGER, 2003). Ou seja, embora a laicidade burocrática seja real, de maneira geral a secularização desses estabelecimentos não ocorreu. Nesse caso, a relação entre secular e religioso opera a partir de um sistema de seletividade no qual as manifestações dos ritos católicos persistem ordenando a lógica espaço-ritual.

Hirschkind ${ }^{12}$ (2017: 182-183) esclarece que é na prática de distinguir o religioso do secular que constituímos o último. A partir daí ele conclui que quando tentamos caracterizar disposições seculares ignorando a religião, perdemos o sentido a que o secular se refere. Retomando a argumentação do administrador, vemos que ele faz referência à ordem, à limpeza, à arrumação. Essas palavras obviamente podem ser lidas na chave do secular. Afinal, as ações delas decorrentes fazem parte de uma administração laica e nas sentenças estão referidas ao espaço cemiterial. Num contexto geral, elas poderiam não evocar sentidos religiosos. Contudo, apesar de o administrador fazer questão de se colocar no plano do secular, avançando e relacionando cada um dos comportamentos permitidos e tolerados, verificamos que eles abrangem e dialogam com dimensões religiosas.

Sigamos então a indicação de Giumbelli (2013), e procuremos o religioso nos sentidos explicitados pelas palavras que o administrador usou para explicar suas ações. Ele descreveu o tempo pretérito a sua gestão como característico de imundície, abandono, sujeira. Ao contrário das palavras anteriores, estas estão associadas a certos ingredientes: túmulos, propriedade, galinha, despacho. Nesse segundo grupo, podemos perceber que os referentes estão relacionados tanto a componentes do próprio espaço do cemitério (túmulos) e a posse dos mesmos quanto a objetos e seres associados (trazidos por) às religiões afrobrasileiras. Há uma complementaridade de sentidos entre o secular e o religioso. Essa associação impede que façamos uma leitura da administração do cemitério operando apenas a partir do paradigma da modernidade laica.

A compreensão de que o secularismo não implicou na separação entre instituições religiosas e governamentais parecer essencial neste ponto. Afinal, como bem explicou Paula Montero (2012), esse movimento provocou mutações capazes de colocar demandas religiosas nos fóruns decisórios e possibilitar que agentes religiosos colaborem em políticas públicas. Nesse

12 Embora o autor esteja debatendo a respeito do corpo secular, suas colocações me ajudaram a pensar a imbricação religiosa, secular e laica no espaço do cemitério. 
sentido, quando o administrador interdita certos comportamentos explicando que estes sujam, ele o faz em contraposição ao que é permitido e legítimo (orações, velas, flores, pintar e lavar). Percebe-se que em todos os casos ele opera associando referentes religiosos e seculares.

Obviamente, ao contrário do que aconteceu com as regras espaciais, o estabelecimento das novas normas rituais provocou polêmicas. Ao passo que os católicos e evangélicos comemoraram a limpeza do espaço, os adeptos das religiões de origem afro-brasileira não aceitaram tão tranquilamente essas mudanças. $\mathrm{Na}$ tentativa de manter algumas de suas práticas rituais - o que evidencia um desejo de compartilhamento do espaço - eles adotaram estratégias a partir das quais confrontaram a nova organização.

O coveiro e o administrador me contaram que, mesmo depois das proibições, vez por outra, quando chegavam ao cemitério pela manhã, encontravam despachos com sangue e cabeças de animais mortos espalhados pelo chão. Segundo eles, esses cerimoniais eram feitos de madrugada por pessoas que pulavam os muros do estabelecimento. Algumas vezes, os despachos eram lançados por cima do muro em plena luz do dia, desafiando as determinações da direção. Na tentativa de frear essas práticas e de reforçar as novas regras, a prefeitura contratou um vigia noturno.

Essas disputas religiosas desencadeadas localmente pela equipe de conservação expressam uma realidade já consolidada no Brasil. Afinal, os cemitérios brasileiros são palco de disputas religiosas desde o período colonial (REIS, 1991). Contudo, foi no Império que o domínio católico das necrópoles passou a provocar conflitos mais intensos quando foram proibidos enterramentos de não católicos, principalmente de protestantes, de judeus e de maçons. A Igreja Católica, de maneira geral, tendia a manter o controle desses estabelecimentos defendendo a continuidade das "sepulturas eclesiásticas" ${ }^{13}$ como maneira de consolidar o cemitério como extensão do terreno sagrado dos templos (RODRIGUES, 2008: 27).

Retomando os debates a respeito da gestão dos cemitérios no período imperial, verifiquei tentativas de minimizar os conflitos por meio de proposições que já dialogavam com o entendimento dos cemitérios laicos. Por exemplo,

13 Sepulturas eclesiásticas eram consideradas aquelas de católicos que receberam os sacramentos antes da morte. Entre as condições ensejadas para ter direito a tal sepultura estavam: "não ter praticado nos últimos instantes de sua vida qualquer ato que lhe desse direito a ter sepultura eclesiástica": não se arrependera dos erros em matéria religiosa que lhe foram atribuídos, não reconhecera o mistério da Santíssima Trindade, além de ter repelido a confissão auricular" (RODRIGUES, 2008: 27). 
a necessidade de mudança da natureza pública das necrópoles tomou força a partir de 1869. Já na década de 70, do mesmo século, os políticos e intelectuais discutiram longamente a respeito do estabelecimento de legislação para os cemitérios, discorrendo se os mesmos deveriam ser administrados por meio de uma jurisdição eclesiástica ou civil. Em 1879, por exemplo, Saldanha Marinho e Joaquim Nabuco defenderam a liberdade religiosa no país e a causa dos protestantes, enviando um projeto afirmando a necessária jurisdição civil dos cemitérios municipais (RODRIGUES, 2008, p. 31-34).

Todavia, o que ocorria na prática era que, mesmo que separados das igrejas, as necrópoles continuaram sendo administradas por párocos e destinadas ao enterro apenas dos "cristãos católicos" (RODRIGUES, 2008) - o que representava um problema para aqueles que não professavam essa opção religiosa. Diante da exclusividade católica dos enterramentos, as disputas travadas por não católicos que desejavam ser enterrados nos cemitérios públicos das cidades só aumentaram. Afinal, com poucas exceções, esses cemitérios eram os únicos que existiam (LIMA, 2001, p. 91).

Naquele contexto, o que se percebia é que a necrópole pública destinada apenas aos católicos não se enquadrava mais nas demandas dos novos grupos sociais que emergiam na sociedade brasileira. Entretanto, persistia a indistinção entre ser católico e ser cidadão e aqueles que não se encaixavam na ordem religiosa oficial do Estado eram vistos como invasores do universo religioso e elementos promotores da desordem - sendo sucessivamente afastados e discriminados.

O fato é que a laicização dos cemitérios só aconteceu oficialmente em 1890 e o mesmo processo só atingiu os registros de nascimentos, casamentos e óbitos em 1917. Diante dessas mudanças, no contexto contemporâneo, os cemitérios laicos são partilhados por diversos públicos das mais variadas confissões religiosas. Contudo, esse compartilhamento é formado por dinâmicas muito complexas. Afinal, mesmo que atualmente na maior parte das cidades não haja impedimentos aos enterramentos por motivos de pertencimento religioso, o ambiente cemiterial se marca por uma complexa construção hegemônica católica que é herança desses tempos e que se manteve atuando conjuntamente com o processo de secularização dessas instituições.

De toda forma, o que estou propondo aqui é que o diálogo entre referentes religiosos e seculares no ambiente cemiterial contemporâneo opera exclusões rituais e simbólicas utilizando-se de novos arranjos entre marcadores. Esta minha afirmação leva em consideração que há diversas 
polêmicas semelhantes deflagradas em outros cemitérios brasileiros que também dizem respeito ao uso desses estabelecimentos pelos adeptos da umbanda e do candomblé. Uma análise mais detida nas recorrências desses embates nos ajuda a compreender melhor os desdobramentos do nosso caso. Adianto que o ordenamento secular das necrópoles circunscreve os limites estabelecidos para os ritos religiosos nesses ambientes. Afinal, como não há um domínio burocrático-religioso do espaço cemiterial, o que se percebe é que a gramática católica desenvolveu-se aderindo ao secular e se tornando estruturante. Quero me deter neste ponto.

Por exemplo, no município do Rio de Janeiro os conflitos ficaram tão acirrados que foi preciso acercá-los em decreto municipal.

“Art. $2^{\circ}$. É vedado criar restrições ao sepultamento com fundamento em crença religiosa ou discriminação fundada em raça, sexo, cor, trabalho ou convicções políticas, ressalvado o disposto no artigo $8^{\circ}, \int 4^{\circ}$, deste Regulamento.

Art. $3^{\circ}$. Nos cemitérios não se permitirá a perturbação da ordem e tranquilidade, o desrespeito aos sentimentos alheios e a convicções religiosas ou qualquer outro comportamento ou ato que fira os princípios éticos e atente contra os costumes e a dor alheia.

Art. 10. Os cemitérios públicos serão laicos e poderão ser administrados diretamente pelo Município ou explorados mediante concessão.’14

Fazendo uma pesquisa em jornais e revistas nos últimos anos, sobram denúncias de que funcionários dos cemitérios cariocas e paulistas proibiram a entrada de pessoas com roupas brancas, pipocas, frutas ou qualquer objeto que esteja associado aos rituais da umbanda ou do candomblé. Ao mesmo tempo, há registros de que muitos desses rituais são realizados à noite para evitar o confronto com a segurança dos cemitérios. ${ }^{15}$ Inclusive, no Rio de Janeiro e em São Paulo, seguem-se discussões a respeito da possibilidade da construção de áreas específicas para práticas associadas a essas religiosidades. ${ }^{16}$

14 Decreto no. 39.094 de 12/08/2014 - Institui o Regulamento Cemiterial e Funerário do Município do Rio de Janeiro, mediante disciplina da legislação local acerca dos cemitérios e da execução dos serviços funerários da cidade e dá outras providências.

15 Sobre o assunto ler, por exemplo, reportagem do jornal $O$ dia, de $3 / 12 / 2014$, quando uma mãe de santo gravou um vídeo no momento em que foi impedida de entrar no cemitério para prestar homenagens aos seus parentes já enterrados. Disponível em: http://odia. ig.com.br/noticia/rio-de-janeiro/2014-12-03/cemiterios-proibem-cultos-afro.html

16 Há inclusive o projeto de lei 66/2013, que estabelece a necessidade da criação desses espaços específicos nos cemitérios. 
Os adeptos denunciam proibição de ritos, desrespeito a sua tradição, impedimento de entrada. Muitos deles rejeitam a criação desses espaços específicos por compreendê-los como sinônimos de segregação e exclusão.

O caso do cemitério de Praia de Mauá nos permite especificar como atuam esses mecanismos de exclusão ritual altamente sofisticados. Como venho argumentando, o predomínio simbólico do catolicismo na necrópole persiste justamente porque está intimamente associado à sua estrutura histórica (AUTORA, 2011). Dessa forma, como os ritos católicos são percebidos como parte do status quo local, mesmo uma gestão secular não cogitaria interferir na sua lógica ordenadora. Ou seja, no desenvolvimento local, a regulação religiosa foi sendo agregada às disposições características daquele espaço de maneira que estas se tornaram "discriminações positivas" (GIUMBELLI, 2013: 12). Por isso, podemos dizer que a decisão de estabelecer restrições rituais específicas para as religiões de matriz afrobrasileira evidencia a imbricação entre uma lógica administrativa secular e uma gramática católica que regra seu ordenamento e suas disposições.

Ora, como é notório naquele cemitério, a participação nos ritos oficiais do catolicismo é realizada rotineiramente pelos adeptos da umbanda ou do candomblé sem que haja qualquer restrição. Eles enterram seus mortos, assim como participam dos ritos oficiais católicos. Em finados, vi diversos filhos de santo com vestimentas e acessórios específicos acompanhando e participando do "Culto aos mortos" realizado pela diocese católica. Eles colocavam velas no cruzeiro e diante do portão do cemitério. Em momento algum notei qualquer tipo de animosidade em relação à adesão religiosa individual publicamente paramentada dessas pessoas. Quando aderem aos ritos católicos, os praticantes da umbanda e do candomblé não são excluídos do espaço público.

Questionei alguns filhos de santo que encontrei no cemitério a respeito da proibição da realização das oferendas aos mortos. Eles me responderam com certa indignação, afirmando que sempre puderam fazer suas homenagens e que recentemente estavam sendo impedidos de realizar seus ritos característicos. Como já demonstrei, a negativa ritual só foi impetrada parametrizando objetos e seres que estão fora dos ritos católicos e diretamente vinculados aos ritos afro-brasileiros. A presença desses objetos e seres alteraria a configuração daquele território católico. Nesse sentido, é possível ponderar que a ação da administração acaba por proteger o espaço público laico da ação de componentes rituais religiosos não legitimados. No 
que diz respeito aos ingredientes dos ritos afro-brasileiros, a administração secular tem uma ação de neutralidade-exclusão (BARBIER, 2005).

Depois das proibições rituais, os despachos passaram a ser colocados unicamente do lado de fora do portão dos fundos do cemitério. Segundo o coveiro, essa saída fica fechada o tempo todo e os enterros não passam por ela. Esporadicamente ela é utilizada para a passagem do caminhão de limpeza que retira o lixo e os restos de construções. À noite é muito escura e ninguém a vigia. Aproveitando-se dessa brecha da segurança, os praticantes passaram a utilizar com mais frequência essa última fronteira do cemitério para realizar seus rituais. Um lugar que fica escondido, deslocado e foi abandonado. Essa opção acomodou os conflitos e permitiu - mesmo que sob alguma tensão - a continuidade do compartilhamento do lugar, já que a prática extramuros foi tolerada pela administração da necrópole.

Toda vez que questionado, o administrador do cemitério explicou o estabelecimento das regras como uma tentativa de organizar e higienizar o cemitério. A sua intenção com tais medidas foi recuperar o número de sepultamentos e também tornar o ambiente "mais agradável". Ele fazia questão de garantir que nunca pensou em impedir qualquer manifestação de luto, já que reconhece o cemitério como um espaço público preparado especificamente para esta etapa ritual: “os enlutados podem chegar, acender suas velas e rezar sem nenhum problema. Ninguém incomoda eles [sic] não. Agora, sujar não pode não" (ADMINISTRADOR, 27/07/2009).

Repensando os componentes da nova ordem imposta para o cemitério, percebo alguns detalhes interessantes. Pode-se afirmar que o administrador evangélico atua a partir de uma noção de secularidade que não contempla práticas não cristãs. Ou seja, como a determinação dos valores seculares no cemitério está indissociavelmente atrelada aos componentes dos ritos do catolicismo, a lógica ordenadora secular os retifica e legitima.

A predominância católica no sistema da morte e nos cemitérios brasileiros não é novidade. A vela que é o símbolo da intercessão pelos mortos no rito católico (REESINK, 2012) é componente indispensável e pode ser observada em diversos ritos fúnebres, mesmo de não católicos. A presença das cruzes e do cruzeiro em praticamente todos os cemitérios, mesmos os públicos, é outro ponto que evidencia esse lugar organizador do catolicismo no terreno da morte (RODRIGUES, 2008). No caso específico de Praia de Mauá, essa marca é ainda mais evidente já que, como já expliquei, desde o seu surgimento até a atualidade o cemitério não mudou de lugar. Ele sempre 
esteve interligado à Igreja de Nossa Senhora da Guia, seja no seu interior, seja ao seu lado, seja compartilhando seus portões. A presença da catedral, das velas, das cruzes e do cruzeiro aponta e reforça essa identificação.

\section{Administração evangélica secular, ritualidade cristã}

Por fim, há que se considerar também as diretrizes específicas do entendimento evangélico para a dinâmica do espaço já que o administrador do cemitério se identificou a partir dessa afiliação religiosa. Essas diretrizes dialogam de perto com a perspectiva da secularidade. Da mesma forma que também podem ser aproximadas da lógica católica a partir do compartilhamento da cosmologia cristã. Cada um desses parâmetros impõe a esse administrador o uso de diferentes respostas simbólicas e práticas disponíveis.

Para os evangélicos que entrevistei, e com os quais realizei longo trabalho de campo, o uso ritual do cemitério se aproxima muito da dinâmica secular. Afinal, a passagem evangélica pelo cemitério durante todo o cerimonial mortuário é muito breve se restringindo apenas ao cortejo que leva o defunto para a sepultura. Eles não homenageiam os mortos em finados. Não retornam ao cemitério para colocar flores nos túmulos. Não acendem velas nem fazem oferendas intercedendo pelos mortos (AUTORA, 2013).

A própria ordenação do cemitério, tal qual proposta pela equipe da administração, pode ser lida como expressiva de um ideário agnóstico, materialista e laico de simplicidade dos ritos de intercessão pelos mortos. Conversando a respeito do abandono evangélico das sepulturas, o administrador me disse:

Veja bem. Se você for no [sic] cemitério vai ver que o velório do católico e do espírita é muito triste, é muita choradeira. Aquele desespero. Eles desmaiam no momento de descer o caixão. E depois do enterro ficam indo e vindo pra cuidar do túmulo, pra falar com o morto. Onde é que está escrito que é pra orar pelo morto? $\mathrm{Na}$ Bíblia não. [...] Agora, o velório de uma pessoa crente não tem isso. São mais serenos. São mais calmos. Afinal, o crente tem uma esperança na ressurreição no futuro. Então vir no [sic] cemitério botar flores pra quê? Pra quem? [...] Às vezes eu acho até que os crentes esquecem que vão morrer (ADMINISTRADOR, 25/11/2008).

Quando questionei meus interlocutores evangélicos sobre os rituais aos mortos nos cemitérios, ouvi respostas como: "o cemitério é o lugar onde os 
corpos dos mortos são colocados [...]". "Aqui tem alguém? Aqui não tem mais ninguém, já acabou [...]" "Tudo vira pó. O que vale é o que fica. Não tem nada aqui" (DIÁRIO DE CAMPO, datas diversas).

Ao mesmo tempo, os evangélicos percebem o cemitério como um território católico. Quando os enlutados evangélicos caminham pelas suas ruas e vielas, no momento da realização do enterro dos seus mortos, eles observam atentamente as práticas rituais que prioritariamente são realizadas ali e reconhecem-nas como manifestações legítimas do local. Ao realizar seus rituais e ao confrontarem silenciosamente esses hábitos por meio da distribuição dos folhetos, eles procuram demonstrar como pensam a vida e a morte marcando as diferenças entre seus procedimentos e as práticas dos "outros". ${ }^{17}$ Essa diferenciação se evidencia no dia dos mortos quando eles fazem questão de permanecer fora do cemitério ou mesmo diante do seu portão. Ao cruzar o território e olhar o que lá acontece, adquirem argumentos para questionar e discordar do que pertence àquele espaço, sem digladiar abertamente.

É interessante pensar que a hegemonia espacial e ritual católica no cemitério é tão consolidada no imaginário coletivo da morte que mesmo um administrador evangélico não questiona suas bases e segue aderindo ao modelo já estabelecido. Ele não cogita reestruturar a parte frontal do cemitério nem proibir as práticas rituais católicas. Não há possibilidade de enfrentamento do que é fundante, mesmo que existam diversos argumentos por meio dos quais ele pudesse justificar uma possível tentativa de transformação. Do ponto de vista da limpeza, o administrador inclusive me relatou que, por exemplo, precisa mandar pintar os degraus do cruzeiro e o muro do portão de entrada quase toda semana para retirar o tom escurecido das chamas das velas colocadas pelos enlutados. No que diz respeito ao acesso, o coveiro me falou e, eu mesma pude observar, a enorme dificuldade que é conduzir um caixão por entre os túmulos do primeiro segmento do cemitério. As flores, vasos e bilhetes colocados nas sepulturas e no chão geram montanhas de lixo que são recolhidas no dia dos mortos pelos caminhões de limpeza. Nenhum desses argumentos seria suficientemente forte para que a lógica ordenadora daquele espaço fosse questionada.

Ao mesmo tempo, nesse caso específico, há uma aproximação efetiva entre evangélicos e católicos que compartilham a cosmologia do cristianismo

\footnotetext{
17 A referência aos católicos como "outros" foi feita por alguns dos meus entrevistados. Insiro o termo da mesma forma como ouvi para dar ênfase à diferenciação presenciada.
} 
e se apropriam do espaço público cemiterial como um "território cristão". ${ }^{18}$ Como um bloco disforme e híbrido, "os cristãos" percebem as práticas religiosas que ali podem e devem ser realizadas a partir da "territorialidade cristã". Para eles, o cemitério é compreendido como espaço exclusivo para o enterramento e para os ritos de luto cristãos. Qualquer prática religiosa que fuja a esse objetivo é compreendida como profanadora daquele território. $\mathrm{O}$ cemitério é o território da morte e a morte é a passagem para a vida eterna no paraíso (no segundo caso via purgatório). E, mesmo havendo diferenças entre usos católicos e evangélicos do espaço, há compartilhamento dos conteúdos mínimos da cosmologia e do rito cristão que não inclui entidades da dinâmica politeísta africana ou sacrifícios de sangue. Assim sendo, as manifestações das religiosidades de matriz africana são percebidas e combatidas como ilegítimas. ${ }^{19}$

Enfim, a nova ordem inaugurada representa um impulso possível de transformação e evidencia quais são os limites para os simbolismos presentes naquele espaço. Afinal, ao propor regras e ao proibir usos, o que o administrador fez foi reduzir ao mínimo possível as relações cotidianas entre vivos e mortos. As que permanecem são apenas as que não poderiam ser contestadas. De certa forma, a secularização do cemitério é a tendência imaginada por ele como "ideal".

Diante desses fatos, acredito que a atitude de enfrentamento e tolerância do administrador confirma os estatutos socialmente estabelecidos. Limpar, arrumar, higienizar são impulsos de quem deseja organizar (DOUGLAS, 1976). E, da mesma forma como existe uma estrutura organizativa fundante do espaço, a sua atitude encarna as fronteiras e porosidades constituintes do macrocosmo da cidade e daquele microcosmo: as convivências e os enfrentamentos próprios do espaço público compartilhado.

De forma mais geral, os movimentos e sentidos apresentados pelos atores desse ambiente reforçam a lógica de porosidade do distrito, onde

\footnotetext{
18 Aqui utilizo o termo território seguindo de perto a definição proposta por Haesbaert (2007: 20-21): “Território, assim, em qualquer acepção, tem a ver com poder, mas não apenas ao tradicional 'poder político'. Ele diz respeito tanto ao poder no sentido mais explícito, de dominação, quanto ao poder no sentido mais implícito ou simbólico, de apropriação. Lefebvre distingue apropriação de dominação ('possessão', 'propriedade'), o primeiro sendo um processo muito mais simbólico, carregado das marcas do 'vivido', do valor de uso, o segundo mais concreto, funcional e vinculado ao valor de troca".

19 A esse respeito ver, por exemplo, Maggie (1992) que, analisando a criminalização religiosa no início do século XX, argumenta que as práticas das religiões afro-brasileiras foram associadas à magia que produzia malefícios.
} 
obviamente há espaços para todos. No entanto, a organização social e as diretrizes a partir das quais ela foi sendo construída são predominantemente católicas. Na dinâmica do cemitério secular, da mesma forma, todos podem entrar e passar para enterrar ou homenagear os mortos. É um espaço de uso comum. Contudo, nem todas as formas rituais são "legítimas", nem todas as conformações espaciais são "preferidas". Ilegítimos e preteridos são os usos reconhecidos como sintomáticos do que está "fora do lugar" ou do que não é "tradicional". ${ }^{20}$ Sendo, portanto, combatidos e proibidos.

Quando o administrador agiu na perspectiva secular e ordenadora, sepultando os mortos mais recentes na parte mais antiga e "desordenada do cemitério", ele adotou o mesmo parâmetro dos enlutados que preferem sepultar seus mortos nessa parte e reforçou ainda mais o que já estava estabelecido - mesmo que não tenha percebido esse fato. Ao mesmo tempo, no que diz respeito aos ritos, quando ele determinou o que é poluidor, utilizou esse mesmo sistema hegemônico agregado a uma dinâmica secular. Os ingredientes e objetos que sujam ou incomodam são aqueles que não podem ser enquadrados nas manifestações de intercessão seculares ou católicas.

Esse argumento pode ser esclarecido quando analiso a fala dos meus entrevistados católicos. De acordo com meus interlocutores católicos, duas coisas os incomodam no cemitério. A primeira delas é o hábito evangélico de distribuir folhetos no Dia dos Mortos. Eles percebem essa atitude como afronta ao seu luto: "viemos ao cemitério colocar flores porque temos saudade, será que eles não podem entender?” (CATÓLICO, 02/11/2009). O segundo incômodo é provocado pelos despachos colocados nos túmulos: "é uma sujeira, uma porcaria" (CATÓLICO, 25/05/2010). Segue-se daí a admiração com o novo momento em que "o cemitério está lindo, limpo. Uma maravilha” (IDEM).

Ao impedir a expressão ritual de "alguns", a administração do cemitério não desejava incitar confrontos - conforme explicou o administrador. Ao mesmo tempo, só proibiu ingredientes religiosos distintos dos utilizados pelos cristãos. A proibição de certas práticas informa que sua realização

20 A tentativa de fazer atividades parecerem idênticas ou consistentes com velhos precedentes culturais pode ser chamada de "tradicionalismo". Como uma poderosa ferramenta de legitimação, tradicionalismo pode ser a matéria de repetição de atividades de um período anterior, a adaptação de atividades em novas ou a criação de práticas que simplesmente evocam ligações com o passado. As mais óbvias formas de tradicionalismo incluem o uso de costumes antigos, a repetição de velhos costumes e a preservação de antigas formas linguísticas (BELL 1997: 145). 
não é compreendida como legítima para aquele ambiente. Não faz parte da estrutura do lugar. O que evidencia um entendimento semelhante ao que ordena a lógica ali estabelecida e também demonstra os limites para a filtragem que ele pode realizar.

Enfim, no interior desse campo, representado aqui pelo cemitério, as continuidades e as rupturas são constantemente retomadas e reforçadas a partir do cotidiano de encontros e desencontros. A atitude do administrador guarda em si mais do que apenas um estímulo organizador. Ele lida com uma ordem secular que interdita práticas rituais não cristãs. Nesse sentido, percebo uma ação que tende a reforçar o domínio católico dos mortos e as práticas rituais de intercessão que seguem esse modelo.

Os dados aqui apresentados evidenciam ainda mais a dinâmica múltipla dos atores que participam desse processo - mesmo que, ao longo do tempo, esse impulso nada mais possa fazer que reforçar a predominância já existente, atualizada a partir de parâmetros distintos. Digo isso porque, de acordo com as informações que o coveiro e o administrador me forneceram, a maior parte das sepulturas perpétuas recentemente adquiridas na parte de trás do cemitério pertence a não evangélicos. Nesse sentido, o hábito de intercessão pelos mortos - segundo eles - continua forte e, por sua vez, as sepulturas que futuramente constituirão a paisagem do novo cemitério serão de famílias católicas e espíritas do lugar, como já acontecia antes da chegada do novo administrador. De maneira intrigante - pensando numa projeção futura - a formatação parece que não será modificada. Afinal, o cemitério é partícipe de uma estrutura mais ampla que representa a própria sociedade mantida e reproduzida nos ritos que se consagram justamente a esse objetivo.

\section{Considerações finais}

Ronaldo Almeida (2011) vem sustentando a ideia de que, embora o crescimento das igrejas evangélicas no Brasil seja um dado, a projeção futura não garante que os evangélicos serão maioria religiosa no país. Um dos argumentos utilizados pelo autor é que, à medida que o catolicismo se percebe como alternativa no campo religioso, ele se robustece reafirmando sua identidade religiosa. A disputa por adeptos é um sinal de fortalecimento do pluralismo religioso no país.

Seguindo de perto essa argumentação, nota-se que há uma mútua influência entre católicos e evangélicos ao longo dos seus encontros e 
desencontros pelos mais diferentes pontos deste nosso enorme país. Dados demonstram que o catolicismo carismático tem se aproximado muito do modelo evangélico conversionista, emocional e moralizante. Há uma mudança importante no perfil católico a partir do contraste com os evangélicos e sua atuação na esfera pública (MARIANO, 2011) - o que tem feito os movimentos católicos carismáticos se fortalecerem.

Por sua vez, as bancadas políticas religiosas católicas e evangélicas têm atuado como um "bloco cristão" no momento do enfrentamento de pautas relativas aos direitos humanos, sobretudo nos debates a respeito do aborto, do gênero e da sexualidade (MACHADO, 2015; VITAL DA CUNHA e LEITE LOPES, 2012). Nesses embates entre religiosos e laicos fica evidente a construção de uma postura de fundamentalismo. Importante ressaltar que, embora a interculturalidade seja um fato do mundo contemporâneo, verificase a proliferação crescente de radicalismos e de extremismos não somente na esfera religiosa, já que o fundamentalismo pode ser encontrado em diversos contextos, como o econômico, por exemplo (ALVES, 2010: 147).

Neste artigo, procurei demonstrar como o modelo católico histórico é organizador do território da morte e que a postura ativa reorganizadora secular do espaço do cemitério protagonizada por um evangélico guarda em seu cerne elementos interessantes para pensar a centralidade da gramática cristã no espaço público laico. Procurei explicitar que, mesmo diante de uma administração civil, os atores sociais agem ora utilizando-se de preceitos do Estado laico, ora de termos seculares, ora como um "bloco cristão". Esses diferentes referentes simbólicos em junção atuam mantendo e fortalecendo a predominância do cristianismo, ao mesmo tempo em que geram exclusão.

Essa minha aposta se evidencia no compartilhamento do cemitério pelas alternativas religiosas. Vejamos: embora os católicos tenham me dito que se sentiam incomodados com as práticas rituais das religiosidades afrobrasileiras, não há evidências de ações explícitas destes para confrontar e expulsar esses atores e seus ritos daquele espaço. Neste caso, em especial, o que transparece é que somente a chegada do administrador evangélico, que protagoniza um intervencionismo secular, acionou o confronto mais direto naquele sistema de convivência entre religiosidades. Ou seja, foi somente a partir das ações de ordenamento e higienização promovidas pela gestão secular do evangélico que os católicos se posicionaram favoráveis ao modelo secular e religioso espacial excludente. De maneira concomitante, é importante ressaltar que o uso dos marcadores de ordenamento e higienização 
a partir de um intervencionismo laico legitima as ações excludentes já que, no momento da imposição das proibições, o administrador não se apresenta nem se considera agindo como evangélico e sim como gestor.

Embora tenham diferenças entre si - no que diz respeito ao conteúdo dos ritos de morte, na compreensão do que é a vida após a morte, do destino dos mortos e da influência dos vivos sobre os mortos - católicos e evangélicos compartilham certos sentidos estruturais e se uniram produzindo e consolidando juntos um ambiente que impossibilita certas expressividades rituais. Explicita-se, neste caso, que somente a consolidação de uma união de sentidos de uma administração secular e de uma territorialidade cristã foi capaz de expulsar do interior do cemitério público práticas religiosas não cristãs. Nesse sentido, a multiterritorialidade a partir da qual o espaço público laico deve ser compartilhado cede espaço a uma prática territorial que legitima um modelo religioso específico: o cristão.

Pensando na ampliação deste debate, acredito que a sociedade brasileira deve ser problematizada a partir de tonalidades de fundamentalismos. ${ }^{21} \mathrm{Não}$ um fundamentalismo que nos leve a homogeneizar grupos cristãos e não religiosos. Há ondas de conservadorismo diversas e com distintas gradações, mas todas elas vão a caminho da mesma praia. ${ }^{22}$ De modo diferente da proposta weberiana, na secularização operada na necrópole mauaense, ao invés da religião ser retirada do espaço público, ela é recolocada por meio de uma agregação entre o religioso e o secular. Avançando neste argumento, observa-se que o ascetismo protestante sofistica o processo, já que se legitima por intermédio da utilização de marcadores laicos.

Sabemos que o fundamentalismo especificamente cristão é disforme e híbrido e guarda em si enquadramentos que devem ser melhor compreendidos. Certos grupos de católicos e de evangélicos têm apostado em trechos das Sagradas Escrituras como balizadores das condutas morais dos cidadãos brasileiros - mesmo aqueles que se identificam como sem religião ou como pertencentes a outras religiosidades. Esses grupos não dissociam

21 José Alves (2010: 24) explica que o fundamentalismo não é terrorismo, especialmente na esfera da religião. Não necessariamente significa rejeição total de crenças e comportamentos diferentes. Nesse caso, sua atuação é sofisticada já que se utiliza de diferentes referentes, inclusive o laico.

22 Aqui remeto o leitor à fala de Ronaldo Almeida (2016) no último encontro da ABA realizado em João Pessoa, em que ele falava da onda conservadora que se desenvolve a partir de uma cultura bíblica cristã. Embora o debatedor se referisse diretamente ao conservadorismo, eu utilizo como recurso para ir ao fundamentalismo. 
cidadão de cristão (MARIANO, 2011). Negar a postura fundamentalista poderosa que (res)surge no encontro desses grupos seria um equívoco, já que a partir dela deslegitima-se o lugar de fala de muitos, retiram-se direitos de outros e se desumanizam as ações de alguns. Importante acrescentar que, como procurei evidenciar, a bandeira do Estado laico é hasteada potencializando esses atos, já que não viabiliza a associação direta entre a exclusão ritual e a opção religiosa.

O fundamentalismo cristão me inquieta pessoalmente a partir de uma dupla preocupação como pesquisadora da antropologia das religiões. Primeiramente, penso que essa constatação seria interessante por retirar "dos evangélicos" (uma postura generalista senso comum) a alcunha de fundamentalistas e conservadores. A constatação de uma tendência para a consolidação de comportamentos fundamentalistas cristãos em construção - que associa certos evangélicos e alguns católicos - pode contribuir para diminuir o preconceito contra "os evangélicos" que ainda são vistos como "os intolerantes". Ao reconhecer no catolicismo a junção da já comprovada hegemonia organizadora com esse traço autoritário, que vem se evidenciando contemporaneamente a partir da consolidação do pluralismo religioso e também da formação das bancadas parlamentares religiosas, nós, pesquisadores, poderíamos questionar mais profundamente a intolerância como um fenômeno da realidade brasileira para fora apenas do debate religioso restrito, mas alcançando mesmo o espaço público laico e afetando os cidadãos.

Ao mesmo tempo, como estudiosos das diferentes denominações evangélicas e também dos segmentos múltiplos do catolicismo, temos sido constrangidos e desafiados em nosso "relativismo metodológico". Não queremos ser "amoladores de faca".

"Diante deste cenário, tomá-los como religiosos e fazer o esforço relativista de buscar compreendê-los nos torna também, de algum modo, "amoladores de faca". Não é possível negar a expertise política que lhe caracterizam em prol da indicação de que são "religiosos" e/ou como "apenas" atores que transportam seus valores religiosos para um espaço historicamente definido como "laico". Há, na verdade, um projeto claro de expansão de poder e domínios que pede que estejamos em vigilância. Com um movimento ascendente ao longo dos anos, é possível observar esse grupo ampliando as suas forças nas diferentes estruturas do poder e desqualificando processos, meios, caminhos que poderiam conduzir a uma maior igualdade entre os sujeitos; influenciam eleições, ganham espaços no Executivo e são atores fundamentais em barganhas características de algumas Casas legislativas (...), 
as associações dessa Frente com a "bancada ruralista" (...), e a sua articulação com a "bancada da bala" (LEITE LOPES, 2014: 90).

O relativismo tem nos levado a lugares incômodos. Diante disso, acredito que apostar na crítica da existência de um processo que aponta para a consolidação de grupos que reivindicam para si certo fundamentalismo cristão pode ser um caminho que nos ajude a deslegitimar essas falas, demonstrando a partir de dados de pesquisa como elas se consolidam, como dialogam entre si e com a dinâmica da secularidade e como excluem cotidianamente aqueles que estão fora dessa grande estrutura de sentidos que é histórica e que se reforça no presente.

\section{Referências}

ALMEIDA, Ronaldo (2011). "O que significa o crescimento evangélico no Brasil?”. Le monde diplomatique (Brasil). São Paulo, p. 18-19.

. (2016). Gênero, sexualidade, intolerância e violência. Reunião da Associação Brasileira de Antropologia, João Pessoa (apresentação oral). 2017: e175001.

. (2017). A onda quebrada - evangélicos e conservadorismo. Cadernos Pagu (50),

AUTORA (2013). "Aproximando-se dos vivos e afastando-se dos corpos dos mortos: o rito de enterro evangélico e seu caráter de moralidade." Ciências Sociais e Religião, Porto Alegre, 15 (18), p. 89-111.

. (2011). Ritualizando o enterro e o luto evangélico: compartilhamento e incomunicabilidade na experiência da finitude humana. Rio de Janeiro: Tese de doutorado, Universidade do Estado do Rio de Janeiro.

ALVES, José Augusto Lindgren (2010). Coexistência cultural e "Guerras de Religião". RBCS, $25, \mathrm{n}^{\circ} .72$, fev. p. 21-35.

BARBIER, Maurice (2005). Por uma definición de la laicidade francesa. Revue Le Debat, $\mathrm{n}^{\circ} .134$.

BASTIDE, Roger (2001). O candomblé da Bahia. Rito Nagô. São Paulo: Companhia das Letras. BELL, Catherine (1997). Ritual perspectives and dimensions. Oxford: Oxford University Press. BERGER, Peter (2003). O Dossel Sagrado. São Paulo: Paulus.

DOUGLAS, Mary (1976). Pureza e perigo. São Paulo: Editora Perspectiva.

GIUMBELLI, Emerson (2008). "A presença do religioso no espaço público: modalidades no Brasil.” Religião e Sociedade, Rio de Janeiro, 28 (2), p. 80-101.

. (2013). Para estudar a laicidade, procure o religioso. In: GIUMBELLI, E. e BELIVEAU, Veronica (Orgs.). Religión, Cultura y Política en las Sociedades del Siglo XXI. Buenos Aires: Biblos. 
HAESBAERT, Rogério (2007). “Território e multiterritorialidade. Um debate.” Geografia, v. 9, n. 17 , p. 19-46.

(2004). Dos múltiplos territórios as multiterritorialidades. Anais do IX Encontro Nacional da ANPUR, v. 3. Rio de Janeiro: ANPUR.

HIRSCHKIND, Charles (2011). Is there a secular body? Cultural Anthropology, 26, Issue 4, p. 633-647.

LEITE LOPES, Paulo Vitor (2014). Religião e política: algumas considerações sobre conflito e posições. Comunicações do ISER, v. 69, p. 80-90, 2014.

LIMA, Sergio Prates (2010). Robert Reid Kalley: de médico dançarino em Kilmarnock a médico missionário no Brasil, 2010. Dissertação (Mestrado em História) - Instituto de Filosofia e Ciências Humanas, Universidade Federal Rural do Rio de Janeiro.

MACHADO, Maria das Dores Campos (2015). "Religião e política no Brasil contemporâneo: uma análise dos pentecostais e carismáticos católicos." Religião e sociedade, Rio de Janeiro, 35 (2): 45-72.

29-56, 2012.

(2012). Religião, cultura, política. Religião e Sociedade, Rio de Janeiro, 32 (2):

MAFRA, Clara e ALMEIDA, Ronaldo (2009). Religiões e cidades: Rio de Janeiro e São Paulo. São Paulo: Editora Terceiro Nome.

MAGGIE, Yvonne (1992). Medo do feitiço: relações entre magia e poder no Brasil. Rio de Janeiro: Arquivo Nacional.

MARIANO, Ricardo (2011). "Laicidade a brasileira. Católicos, pentecostais e laicos em disputa na esfera pública.” Civitas, Porto Alegre, v. 11, n. 2, p. 238-258, mai./ago.

MARTINS, Jose de Souza (1983). A morte e os mortos na sociedade brasileira. São Paulo: Editora Hucitec.

MONTERO, Paula (2006). "Religião, pluralismo e esfera pública no Brasil." Novos estudos 74, São Paulo, p. 47-65.

ORO, Ari Pedro. A laicidade no Brasil e no Ocidente. Algumas considerações. Civitas. Porto Alegre, v. 11, n. 2, p. 221-237, mai./ago. 2011.

REESINK, Mísia (2012). "Quando lembrar é amar: tempo, espaço, memória e saudade nos ritos fúnebres católicos.” Etnográfica, Portugal, v. 16 (2).

REIS, João José dos (1991). A morte é uma festa. Ritos fúnebres e revolta popular no Brasil do século XIX. São Paulo: Companhia das Letras.

ROCHA, José Geraldo da Rocha; PUGGIAN, Cleonice e RODRIGUES, Luana (2011). Religiões de matrizes africanas: dilemas da intolerância na contemporaneidade. Debates do NER, Porto Alegre, 20 p. 145-164.

RODRIGUES, Claudia (2008). "A arte de bem morrer no Rio de Janeiro Setecentista.” Varia História, Belo Horizonte, 27 (39), p. 255-272. 
TEIXEIRA, Faustino, MENEZES, Renata et al. (2006). As Religiões no Brasil: Continuidades e Rupturas. Petrópolis: Vozes.

VITAL DA CUNHA, Christina; LOPES, Paulo Victor Leite; LUI, Janayna (2017). Religião e Política: medos sociais, extremismo religioso e as eleições 2014. Rio de Janeiro: Fundação Heinrich Böll: Instituto de Estudos da Religião.

WEBER, Max. Economia e sociedade. Fundamentos para uma sociologia compreensiva, v. I. Brasília: Editora Unb, 2004.

Submetido em: 13-11-2017

Aceito em: 20-8-2018 